\title{
Effect of Vernonia amygdalina Del. Leaf Ethanolic Extract on Intoxicated Male Wistar Rats Liver
}

\author{
Maria Immaculata Iwo ${ }^{1,2, *}$, Sergia Louisa Sjahlim ${ }^{1}$ and Siti Farah Rahmawati ${ }^{1}$ \\ 1 Pharmacology Clinical Pharmacy Research Group, School of Pharmacy, Institut Teknologi Bandung, \\ Jl. Ganesha 10, Bandung 40132, Indonesia; sergialouisa@yahoo.co.id (S.L.S.); siti.farah@fa.itb.ac.id (S.F.R.) \\ 2 Biotechnology Biomedical Research Center, Institut Teknologi Bandung, Jl. Ganesha 10, \\ Bandung 40132, Indonesia \\ * Correspondence: maria@fa.itb.ac.id; Tel.: +62-22-856-220-2445
}

Academic Editor: Gernot Eller

Received: 29 December 2016; Accepted: 16 March 2017; Published: 23 March 2017

\begin{abstract}
Vernonia amygdalina has been shown to have antioxidant activity, and is also expected to have hepatoprotective activity. This study was conducted to study the effect of $V$. amygdalina ethanol extracts on intoxicated rat livers. Fresh leaves were extracted in ethanol, and the hepatoprotective activity was tested on male Wistar rats induced with a combination of isoniazid (INH) and rifampicin. Parameters observed were the activity of the enzyme alanine transferase (ALT), serum albumin levels, liver index, and histopathological of the rat liver. The results showed that 50 and $100 \mathrm{mg} / \mathrm{kg}$ rat body weight of $V$. amygdalina ethanol extracts could prevent liver intoxication, starting on day 14 . Based on serum albumin concentrations and ALT activity, the high dose extract $(100 \mathrm{mg} / \mathrm{kg})$ was more potent as a hepatoprotective agent compared to the extract at a low dose (50 mg/ $\mathrm{kg}$ ). The group of rats treated with a high dose extract showed normal liver index compared to the positive control. Through histology examination, the liver of rats treated with a high dose extract $(100 \mathrm{mg} / \mathrm{kg})$ showed minimal liver cell structure damage, and showed similar patterns to the normal rat. Based on these results, it can be concluded that $V$. amygdalina ethanol extracts can be used to protect the liver in a combination of INH and rifampicin as antituberculosis treatment.
\end{abstract}

Keywords: intoxicated rat liver; Rifampicin; INH; Vernonia amygdalina

\section{Introduction}

The metabolism of drugs and other exogenous compounds mainly takes place in the liver [1]. In addition, most drugs are administered orally and are absorbed from the gastrointestinal tract to the tissues through the liver. Thus, the liver is liable to damage from such drugs and their metabolites [2]. Three of the main drugs responsible for liver damage in patients include tuberculosis (TB) medication, anticancer drugs, and antibiotics.

Tuberculosis remains a major health problem in South-East Asia and is one of the highest causes of morbidity and mortality. It is also the second highest cause of adult deaths after cardiovascular disease, and is the deadliest pathogen out of all the communicable diseases; there are about half a million cases of smear-positive TB in Indonesia. Due to this high rate of incidence of TB, many patients prescribed anti-TB drugs also suffered damage to the liver. According to research by Nurazminah conducted in a hospital in the cities of Jakarta and Cisarua, Indonesia, the percentage of respondents who experienced liver damage caused by anti-TB drugs was $52.2 \%$ [3].

In tuberculosis patients, chemotherapy combination drugs are known to cause toxicity of the liver (hepatotoxiticy). Previous studies have shown a 10\% elevation of serum hepatocellular enzymes, and a withdrawal of $1-2 \%$ of patients who took a standard combination chemotherapy of isoniazid (INH) and rifampicin was seen because of severe hepatotoxicity leading to fulminant hepatitis [4]. Rifampicin 
is a strong inducer of Cytochromes P450 (CYP450) in the liver, and its combination with INH has been related to an increased risk of hepatotoxicity. Rifampicin induces INH metabolism, therefore increasing hydrazine production (especially in slow acetylators), which can escalate the toxicity [5].

Liver damage can be prevented by using hepatoprotective agents-compounds that mitigate liver damage caused by hepatotoxic agents. Hepatoprotective agents are used in patients suffering from various liver diseases. Several medicinal plants have been known to have hepatoprotective activities, including Eclipta alba (Asteraceae), Glycyrrhizaglabra (Leguminosae), Boerhaaviadiffusa (Nyctaginaceae), Phyllanthusamarus (Euphorbiaceae), and Silybummarianum (Compositeae). Vernonia amygdalina is a shrub that grows throughout tropical Africa and South-East Asia [6]. The plant is generally known as bitter leaf due to the bitterness of its leaves. Based on previous research [7-10], V. amygdalina has been shown to have antioxidant activities by scavenging free radicals, and is also expected to have hepatoprotective activities. This study was conducted to evaluate the hepatoprotective effect of $V$. amygdalina ethanolic extracts in an anti-TB drug-induced animal model.

\section{Materials and Methods}

\subsection{Plant Material}

Vernonia amygdalina plants were collected from Salaman Magelang, Central Java, and identified at the Indonesian Institute of Sciences, Research Center for Biology. The identity of the plants collected for this study was determined by the Research Center for Biology, Indonesian Institute of Sciences No 1806/IPH.1.01/If.07/VIII/2016 as Vernonia amygdalina Delile, a plant of the Compositae family.

\subsection{Extraction of V. amygdalina}

Fresh leaves were air-dried and processed into crude drug. Then, the dried powder was extracted in ethanol $96 \%(v / v)$ using the Soxhlet method. The obtained extract was then concentrated using a rotary evaporator and was then characterized.

\subsection{Extract Characterization and Phytochemical Screening}

The characteristics of extract were determined according to methods described by Harborne through the following quality parameters: water content, water extractable matter, ethanol extractable matter, extract density, and phytochemical screening [11].

\subsection{Animals}

Male Wistar rats weighing about 200-250 g and ages 10-12 weeks old were obtained from PT Bio Farma, Bandung. The animals were distributed into stainless steel cages (five rats per cage). They were fed a standard diet and water ad libitum. The animals were maintained under standard laboratory conditions: free air circulation, room temperature of about $22-25^{\circ} \mathrm{C}$, and humidity of $55-60 \%$. All rats were acclimatized for 5 days before the experiment. Handling of the animals were guaranteed since the principal investigator has an Animal Welfare Assurance by the office of laboratory animal welfare, $\mathrm{NIH}$, number A5925-01.

\subsection{Evaluation of Hepatoprotective Activity}

A combination of INH and rifampicin were used as inducers of liver damage [5,12], and silymarin was used as the reference hepatoprotective drug. The drug combination was administered orally $1 \mathrm{~h}$ before extract administration. The animals were divided into four groups, each group consisting of five animals. Group 1 served as the control group, which was given INH at a dose of $27 \mathrm{mg} / \mathrm{kg}$ body weight (bw) and rifampicin at a dose of $54 \mathrm{mg} / \mathrm{kg}$ bw. Groups 2 and group 3 were treated with the inductor combination and V. amygdalina ethanol extract at a dose of 50 and $100 \mathrm{mg} / \mathrm{kg} \mathrm{bw}$, respectively, for 35 days. In Group 4, the animals received the inductor combination and silymarin at a dose of $54 \mathrm{mg} / \mathrm{kg}$ bw. The parameters observed were alanine transferase (ALT) activity, serum albumin levels, 
and the liver index. Rats liver histopathological examination was also performed. The albumin level and ALT were measured using analytical kits obtained from Sclavo Diagnostics International, Sovicille Siena, Italy. The liver index was calculated as follows:

$$
\text { Liver Index }=\frac{\text { liver weight }}{\text { body weight }} \times 100
$$

After 35 days, the rats were killed through humane procedures using $\mathrm{CO}_{2}$ gas, and the livers were then collected for histological assessment.

\subsection{Histological Assessment}

Livers from rats of different groups were fixated in 10\% neutral formalin solution, dehydrated in graded alcohol, and embedded in paraffin. Fine sections were obtained, mounted on glass slides, and counter-stained with hematoxylin-eosin for light microscopic analysis.

\subsection{Statistical Analysis}

The results are presented as mean \pm standard deviation (SD). Analyses were performed using a Student's $t$-test. $p$-values less than 0.05 were considered statistically significant [13].

\section{Results and Discussion}

The ethanolic extract of the plant showed the characteristics presented in Table 1.

Table 1. Characteristics of the extract.

\begin{tabular}{cc}
\hline Quality Parameters & Results \\
\hline Water extractable matter (\%) & 7.7 \\
Ethanol extractable matter $(\%)$ & 15.9 \\
Density for 1\% extract $(\mathrm{g} / \mathrm{mL})$ & 0.7 \\
Water content $(\%)$ & 8 \\
\hline
\end{tabular}

The extractable matter content can be used to determine the amount of active constituents that were extracted in the solvent used, as well as the solubility of the active constituents of extract in different solvents. Based on the results, the ethanol extract of $V$. amygdalina had poor solubility in water but high solubility in ethanol. Furthermore, from the phytochemical screening (Table 2), it can be observed that the V. amygdalina ethanol extract contained alkaloids, flavonoids, saponins, and steroid/triterpenoids.

Table 2. Phytochemical screening.

\begin{tabular}{cc}
\hline Compound & Results \\
\hline Alkaloids & + \\
Flavonoids & + \\
Saponins & + \\
Tannins & - \\
Quinones & - \\
Steroid/Triterpenoids & + \\
\hline
\end{tabular}

$+=$ contained; $-=$ not contained

The serum ALT activities of the animals in each group are presented in Table 3. It can be observed that after seven days of INH and rifampicin administration, the ALT activity of all groups was elevated, indicating that all of the animals' livers were damaged. The significant increase in ALT activity on day 
7 shows that the combination of INH and rifampicin damage the liver. Throughout the experiment, the ALT activity of the control $(+)$ group remained significantly higher $(p<0.01)$ compared to those of the treated groups. This indicates that $V$. amygdalina ethanol extract at the doses used can prevent liver damage. The results also show that the two doses of $V$. amygdalina extract used seemed to have same effect in lowering ALT activity starting after 7 days. Of the two doses, it seems that the higher dose was more potent compared to the lower dose. This is seen from the ALT activity of the group treated with $V$. amygdalina extract at a dose of $100 \mathrm{mg} / \mathrm{kg}$ bw, in which after only 14 days the value was no longer significantly different than that at day 0 . Meanwhile, the ALT activity of the group treated with $50 \mathrm{mg} / \mathrm{kg}$ bw of the extract needed 35 days to return to normal conditions.

Table 3. Effect of ethanolic extract of Vernonia amygdalina (VA) on serum alanine transferase (ALT) activity.

\begin{tabular}{|c|c|c|c|c|c|c|c|}
\hline \multirow{2}{*}{ Group } & \multirow{2}{*}{$\begin{array}{c}\text { Dose } \\
(\mathrm{mg} / \mathrm{kg} \text { bw) }\end{array}$} & \multicolumn{6}{|c|}{ ALT (U/L) } \\
\hline & & D0 & D7 & D14 & D21 & D28 & D35 \\
\hline Control (+) & 0 & $43.47 \pm 16.24$ & $61.63 \pm 17.16^{x}$ & $80.00 \pm 9.09^{z}$ & $79.57 \pm 8.46^{z}$ & $82.14 \pm 6.64^{z}$ & $84.00 \pm 5.29^{z}$ \\
\hline VA extract & 100 & $44.93 \pm 15.01$ & $63.01 \pm 3.01^{\mathrm{z}}$ & $55.75 \pm 4.65^{c, x}$ & $54.00 \pm 5.47^{\mathrm{c}}$ & $49.00 \pm 4.24^{c}$ & $47.37 \pm 4.89^{c}$ \\
\hline $\begin{array}{l}\text { Reference } \\
\text { (silymarin) }\end{array}$ & 54 & $42.56 \pm 12.22$ & $54.56 \pm 7.88^{y}$ & $49.42 \pm 3.10^{c}$ & $50.42 \pm 6.39^{c}$ & $48.86 \pm 4.74^{\mathrm{c}}$ & $46.57 \pm 5.80^{c}$ \\
\hline
\end{tabular}

Values are expressed as mean \pm standard deviation (SD). $n=5$; Data was analyzed by students $t$-test, where a $=p<0.1$,

$\mathrm{b}=p<0.05, \mathrm{c}=p<0.01$ compared to induced control (+) group; $\mathrm{x}=p<0.1, \mathrm{y}=p<0.05, \mathrm{z}=p<0.01$ compared to D0.

In addition to the ALT activity, to determine the effect of the extract on liver function, the albumin concentrations were also analyzed. Albumin is synthesized in the liver; therefore, a decrease in serum albumin concentration could indicate liver damage. The albumin levels of each group are presented in Table 4.

Table 4. Effect of ethanolic extract of V. amygdalina on serum albumin concentration.

\begin{tabular}{|c|c|c|c|c|c|c|c|}
\hline Group & $\begin{array}{c}\text { Dose } \\
(\mathrm{mg} / \mathrm{kg} \mathrm{bw})\end{array}$ & \multicolumn{6}{|c|}{ Albumin Concentration (g/dL) } \\
\hline Control (+) & 0 & $3.57 \pm 0.35$ & $3.16 \pm 0.16^{y}$ & $2.91 \pm 0.35^{z}$ & $3.00 \pm 0.32^{z}$ & $2.86 \pm 0.4^{\mathrm{z}}$ & $2.71 \pm 0.31^{y}$ \\
\hline VA Extract & 100 & $3.67 \pm 0.49$ & $3.24 \pm 0.29^{x}$ & $3.46 \pm 0.40^{b}$ & $3.70 \pm 0.43^{c}$ & $3.76 \pm 0.47^{c}$ & $3.79 \pm 0.47^{c}$ \\
\hline $\begin{array}{l}\text { Reference } \\
\text { (silymarin) }\end{array}$ & 54 & $3.43 \pm 0.35$ & $3.11 \pm 0.23^{x}$ & $3.46 \pm 0.40^{b}$ & $3.79 \pm 0.29^{c}$ & $3.83 \pm 0.80^{c}$ & $3.87 \pm 0.46^{\mathrm{cx}}$ \\
\hline
\end{tabular}

Values are expressed as mean \pm SD. $n=5$; Data was analyzed by students $t$-test, where $\mathrm{a}=p<0.1, \mathrm{~b}=p<0.05$, $\mathrm{c}=p<0.01$ compared to induced control (+) group; $\mathrm{x}=p<0.1, \mathrm{y}=p<0.05, \mathrm{z}=p<0.01$ compared to D0.

Daily oral administration of INH and rifampicin for seven consecutive days significantly $(p<0.01)$ altered the rats' liver function, which was characterized by a decrease in serum albumin concentration. However, after 14 days, both extract groups showed no significant changes in albumin concentration compared to the initial condition (D0). In fact, the albumin concentration of these groups increased after the 14th day. These results suggest that both doses of the extract can prevent liver damage.

At end-point of the experiment (D35), the animals were sacrificed and their body weights measured. The livers of the animals were then isolated and weighed to determine the liver index. This parameter was measured to determine the presence of liver enlargement associated with liver damage.

The results of the liver index calculation (Figure 1) showed that the liver index of the group of rats given extract at a dose of $100 \mathrm{mg} / \mathrm{kg}$ bw and silymarin were significantly $(p<0.05$ and $p<0.01$, respectively) lower compared to the control group. Additionally, the liver index of the $100 \mathrm{mg} / \mathrm{kg} \mathrm{bw}$ extract group was no different compared to the group given silymarin, suggesting that the extract at a high dose (100 mg/kg bw) has comparable hepatoprotective activity to the reference drug. 


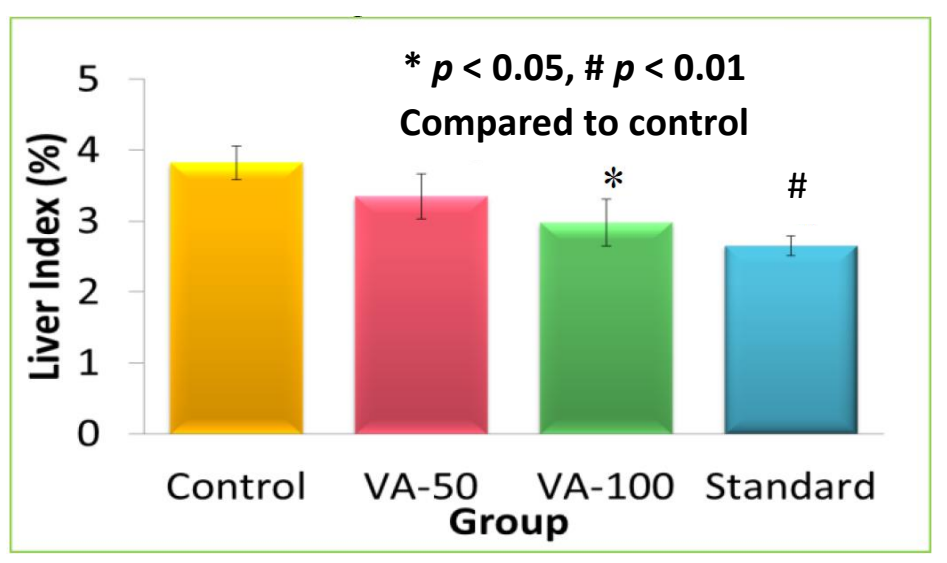

Figure 1. The liver index of the group of rats treated with V. amygdalina (VA) extract.

The pattern and severity of liver damage of each animal in every group was observed by histological observation. The microscopic cross-sections are presented in Figure 2.

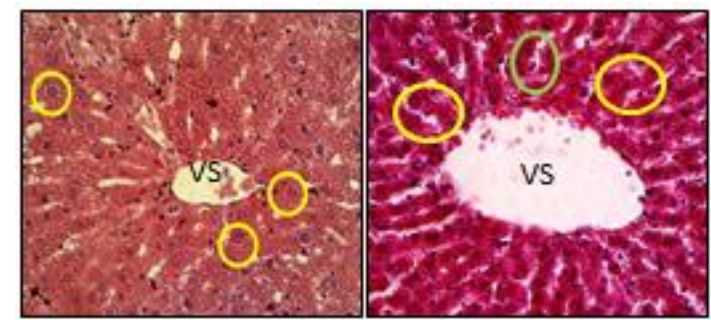

(a)

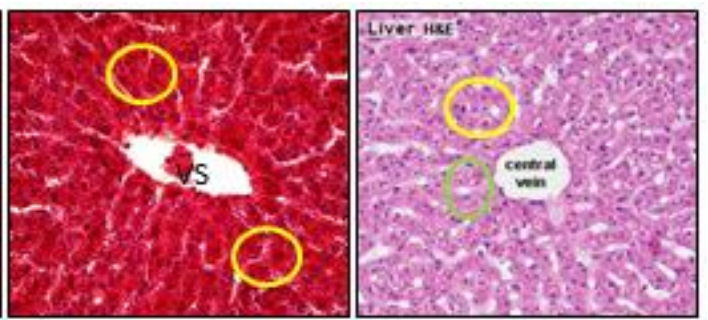

(b)

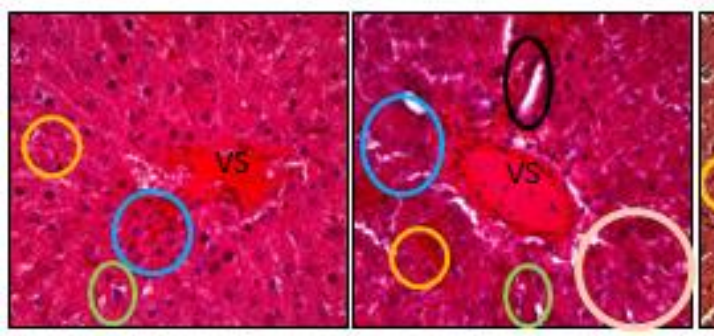

(c)

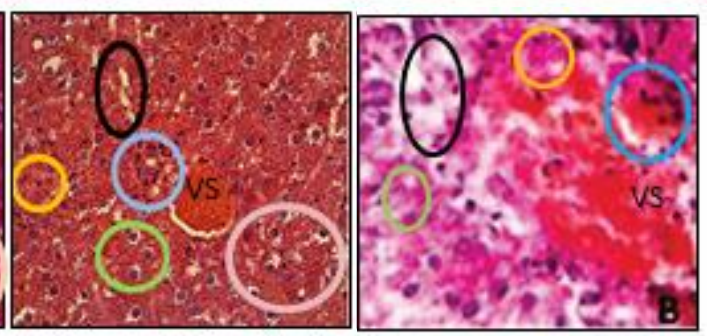

(d)

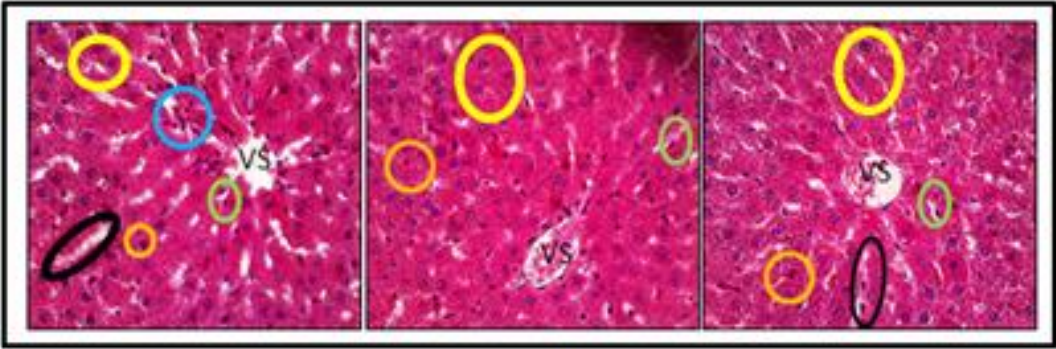

(e)

Figure 2. Cont. 


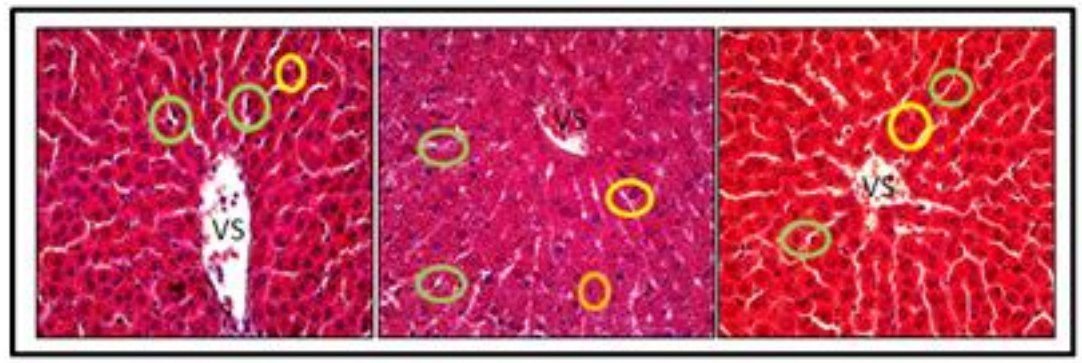

(f)

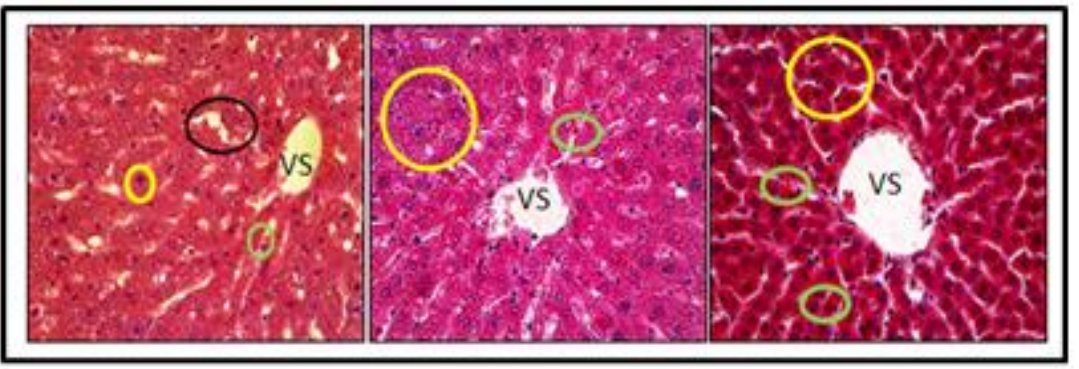

(g)

Figure 2. Histopathological sections of rat's liver. All pictures are magnified $10 \times 10$ times. (a) Normal control group; (b) Histology of the normal liver structure from literature [14]; (c) Positive control group; (d) Histology of the intoxication liver structure from literature [12]; (e) Group treated with extract at a dose of $50 \mathrm{mg} / \mathrm{kg}$ bw and (f) $100 \mathrm{mg} / \mathrm{kg}$ bw; and (g) The reference group. VS marks the central vein, yellow marks show normal hepatocytes, green marks show Kupffer cells, black marks show sinusoid dilatation, blue marks show hydropic degeneration, and orange marks show necrotic cells.

Histopathological examination of the liver sections from normal rats showed normal parenchymal structure, normal sinusoidal architecture, and no significant lesions were observed. In addition, Kupffer cells-phagocytic cells that engulf pathogens, cell debris, and damaged blood cells—could be found in the lining of the sinusoids. According to Sahai et al. [14] and Junqueira [15], profiles of normal liver histology show hepatocytes with a polyhedral shape and a round nucleus at the center $[15,16]$. The positive control group showed changes in liver structure that includes inflammation, hydropic degeneration, and necrosis. The parenchyma showed loss of the normal sinusoidal architecture due to numerous foci of lobular inflammation, hepatocyte dropout, and rosette formation. These results were in line with studies that have shown that the special characteristics of liver damage caused by a combination of INH and rifampin are inflammation and cell necrosis [16,17]. According to Mitchell et al., hydropic degeneration occurs due to a disturbance of active transport that prevents the cellular efflux of $\mathrm{Na}^{+}$ions resulting in an increased concentration of intracellular $\mathrm{Na}^{+}$ions. This causes osmosis and an influx of water into the cells, causing the cells to become swollen and have an enlarged nucleus. Granular in the nucleus are also evident [17].

As for the groups administered $V$. amygdalina extract and silymarin, the liver cell damage was lighter than the positive control group. Liver tissue in the group given $50 \mathrm{mg} / \mathrm{kg}$ bw of extract showed a microscopic appearance with an orderly arrangement. There was still sinusoidal dilation, but neutrophils could be observed accumulated around the central vein, as well as plenty of Kupffer cells. Liver tissue of the group given $100 \mathrm{mg} / \mathrm{kg}$ bw of extract showed lighter liver damage than the $50 \mathrm{mg} / \mathrm{kg}$ bw group, but not better than the group given silymarin. The composition of cells in the liver tissue of the high dose group was regularly arranged, and no visible sinusoidal dilation was observed, although there was also a more regular arrangement of hepatocytes. After administration of silymarin, the liver histology showed only slight damage and approached normal circumstances. 


\section{Conclusions}

A combination of INH and rifampicin given daily for seven consecutive days can cause significant rat liver intoxication. Ethanolic extracts of V. amygdalina leaves at 46 and $92 \mathrm{mg} / \mathrm{kg}$ bw (corrected to its water content) - equivalent to 3.58 and $7.17 \mathrm{~g}$ of dried leaves-were shown to be able to protect liver intoxication caused by a combination of INH and rifampicin.

Acknowledgments: Thank to ITB Biotechnology Biomedical Research Center director for research facility.

Author Contributions: All the authors were involved in the design of the experiments; Segia Louisa Sjahlim performed the experiments, analyzed the data and contributed reagents/materials/analysis tools and wrote the paper; Maria Immaculata Iwo and Siti Farah Rahmawati involve in analyses the data and in the writing and editing of the manuscript.

Conflicts of Interest: The authors declare no conflict of interest

\section{References}

1. Martini, F.; Nath, J.L.; Bartholomeus, E.L.F. Fundamentals of Anatomy and Physiology, 9th ed.; Person Education Inc.: San Frasisco, CA, USA, 2012; pp. 890-895.

2. Davis, M.; Williams, R. Hepatic Disorders. In Textbook of Adverse Drug Reactions; Davies, D.M., Ed.; Oxford University Press: Oxford, UK, 1977; pp. 146-172.

3. Nurazminah, A. Prevalensi Pasien TB Paru yang Mengalami Hepatitis Imbas OAT di RSUP Persahabatan Jakarta dan RSPG Cisarua pada Tahun 2012. Undergraduate thesis, Faculty of Medicine and Public Health, Islamic University of Indonesia, Jakarta, Indonesia, 2012.

4. Barnes, P.F.; Barrows, S.A. Tuberculosis in the 1990s. Ann. Intern. Med. 1993, 119, 400-410. [CrossRef] [PubMed]

5. Chang, K.C.; Leung, C.C.; Yew, W.W. Standard antituberculosis treatment and hepatotoxicity: Do dosing schedules matter. Eur. Respir. J. 2007, 29, 347-351. [CrossRef] [PubMed]

6. Marcia, D.R.D.; Ariane, G.S. Anatomical characters of the medicinal leaf and stem of Gymnanthemum amygdalina (Debile), Sch.Bip. ex Walp. (Asteracea). BJPS 2013, 49, 719-726.

7. Bonsi, M.L.K.; Osuji, P.O.; Tuah, A.K.; Umunna, N.N. Vernonia amygdalina as a supplement to teff straw (Eragrostis tef) fed to Ethiopia Menz, sheep. Agrofor. Syst. 1995, 31, 229-241. [CrossRef]

8. Godwin, O.I.; Wieslaw, O.; Maria, J.; Stanislaw, B.; Michael, F.; Adetunde, A.F. Flavonoids from Vernonia amygdalina and their antioxidant activities. J. Agric. Food Chem. 1994, 42, 2445-2448.

9. Ijeh, I.I.; Ejike, C.E.C.C. Current perspectives on the medicinal potential of Vernonia amygdalina. J. Med. Plant. Res. 2011, 5, 1051-1061.

10. Iwalela, E.O.; Iwalela, O.J.; Adeboye, J.O. Analgesic, antipyretic, anti-inflammatory effect of methanol, chloroform, and ether extracts of Vernonia amygdalina leaf. J. Ethnopharmacol. 2003, 86, 229-234. [CrossRef]

11. Harborne, J.B. Phytochemical Methods: A Guide to Modern Techniques of Plant Analysis, 2nd ed.; Chapman and Hall: London, UK, 1984; 288p.

12. Angala, P.; Saleem, T.S.M.; Chandrasekar, K.B.; Chetty, C.M. Protective role of ficus benghalensis against INH-rifampicin induced oxidative liver injury in rat. Rev. Bras. Farmacogn. 2012, 22, 604-610. [CrossRef]

13. Steel, R.D.G.; Torrie, J.H. Principles and Procedures of Statistics A Biometrical Approach, 2nd ed.; McGraw-Hill International Book Co.: Auckland, New Zealand, 1984.

14. Sahai, A.; Malladi, P.; Melin-Aldana, H.; Green, R.M.; Whitington, P.F. Upregulation of osteopontin expression is involved in the development of nonalcoholic steatohepatitis in a murine model. Am. J. Phyiol. Gastrointest. Liver Physiol. 2004, 287, G264-G273. [CrossRef] [PubMed]

15. Junquiera, L.C.; Corneiro, C. Histologi Dasar, 3rd ed.; Terjemahan Adji, D., Ed.; EGC: Jakarta, Indonesia, 1998; pp. 1-4.

16. Kleiner, D.E. Liver histology in the diagnosis and prognosis of drug-induced liver injury. Clin. Liver Dis. 2014, 4, 12-16. [CrossRef]

17. Mitchell, R.N.; Kumar, V.; Abbas, A.K.; Fausto, N. Adaptasi Sel, Jejas Sel, dan Kematian Sel. In Buku Saku Dasar Patologis Penyakit; EGC: Jakarta, Indonesia, 2008; pp. $2-7$.

(C) 2017 by the authors. Licensee MDPI, Basel, Switzerland. This article is an open access article distributed under the terms and conditions of the Creative Commons Attribution (CC BY) license (http:/ / creativecommons.org/licenses/by/4.0/). 